\title{
療養型病床群における個室ユニット化が職員の行動に及ぼす影響 \\ A STUDY ON EFFECT OF DOWNSIZING CARE WITH PRIVATE ROOM ON STAFFS' BEHAVIOR IN LONG-TERM CARE WARD
}

\author{
孔 相 権, 山中 直**, 三浦 研*** \\ Syohken KOH, Sunao YAMANAKA and Ken MIURA
}

\begin{abstract}
The purpose of this study is to make clear what kind of effect the introduction of downsizing care with private room give staffs'behavior in long-term care ward. The resul t's of the analysis are as follows.

1) A staff' stay place changes drastically from the bed room to the living room.

2) The time of bathing care and excretory care decreased, and the time of meal care increased.

3) It increases the efficiency of the control business, and conversations between the aged and the staff member increase.

4) It cuts down the thing which a gap is with the stay place and the contents of business between the care staff member and the nursing staff member.
\end{abstract}

Keywords : The aged with Long-term Treatment, Downsizing Care with Private Room,

Long-term Care Ward, Care Staff, Nursing Staff

長期療養高齢者、個室ユニット化、療盖型病床群、介護職員、看護職員

\section{1. 研究の背景と目的}

介護保険の導入と共に、在宅ケアやグループホームケアの充実に重 点が置かれている。介護や支援を受けながらも在宅で生活を継続でき ることが望まれるが、特別養護老人ホーム (以下: 特養)、老人保健施 設 (以下: 老健)、療養型病床群 ${ }^{1)}$ などの入所型施設に居住する高齡 者が存在することも事実である。

療盖型病床群は平成 4 年に制度が創設され、病室を 4 床以下、 6.4 $\mathrm{m}^{2} /$ 床以上とし、食事や談話室、機能回復訓練室の設置を義務づけら れている。全国で老人病院からの展開が進み現在 24 万床を超えてい る。医療施設とは本来、急性期疾患の診察、処置、治療の場であり、 患者は治瘑回復すると在宅へ戻ることを前提として、日常生活からか け離れた施設内での入院生活を経験する。しかし、慢性疾患を抱えた 高齢者の場合、在宅復帰することなく施設で生を終えることが少なく ないことを考えると、急性期疾患の患者が入院するような非日常的療 盖環境ではなく、できる限り日常生活に近い療養環境を整備していか なければならない。特養などで居室の個室化や共用空間の充実など生 活の質を高める観点からハードの整備が進んでいる2)現在、療養型病 床群が提供する療盖環境は決して良好なものとは言い難く、特養との 環境面での格差が広がっているのが現状であろう。 また近年、特盖 や老人保健施設といった定員の多い大規模施設においてユニットケア が導入されている。ユニットケア ${ }^{3)}$ とは、大人数の高路者を一括処遇 するのではなく、いくつかの居室や共用スペースを一つのユニットと して整備し、10人程度の少人数ごとに処遇する形態のことである。こ れにより介護職員が入居者と関わりを多く持ち、高齢者のことを十分 に把握した上で、ケアを行うことができると言われている。このよう に療養環境面だけでなくケア面でも格差が広がりつつある。
既往の研究では、グループホームでの少人数処遇やその中での高歯 者の生活展開について扱つた研究4)、特養などの大規模施設で物理的 環境とユニットケア導入による高龄者の生活について扱った研究5)な どが報告されている。しかし、療養型病床群での研究は、グループホー ムや特養などの施設と比較して少なく、研究として未だ十分な蓄積を 得ていない段階であると考える。また、療養型病床群を扱った研究に おいても病室の基準面積や設備の有無など物理的環境面の評価を扱つ たもの ${ }^{6)}$ 、長期療養高齢者の属性、医療・看護ニーズ、身体症状など の基本的特性を把握したもの7)など基礎的知見を提供するにとどまる ものが中心である。施設内での高齢者の生活展開や空間の利用の仕方 などを具体的に明らかにしたもの ${ }^{8)}$ も散見されるが、多床室を中心と した既存の施設での報告であり、個室ユニット化された施設における 職員の滞在場所や行為内容について言及された研究はなされていない。

以上より、本研究では全国で初めて全室個室化し、集団による一括 処遇からユニットケアによる小規模処遇を導入した療盖型病床群を調 査対象として、物理的環境とケアのあり方の違いが、看護職員・介護 職員の行動に与える影響について考察を行う。そして療養型病床群の 療養環境のあり方についての知見と今後の方向性を示唆することを目 的としている。

尚、本研究においては患者のことを長期療養高齢者と表記する。療 養型病床群は医療施設であることを考慮すると、本来ならば入院患者 と表記すべきかもしれないが、本研究では療養型病床群を高齢者が医 療の完備した施設で生活する高齢者福祉施設の一形態として捉え、敢 えて患者という表現は避け、長期療養高歯者（以下: 高龄者）という 表現を使用する。
* 京都大学大学院工学研究科 博士課程 · 工修

** 京都大学大学院工学研究科 修士課程

*** 京都大学大学院工学研究科 助手. 工博
Graduate Student, Graduate School of Engineering, Kyoto Univ., M. Eng.

Graduate Student, Graduate School of Engineering, Kyoto Univ.

Research Assoc., Graduate School of Engineering, Kyoto Univ., Dr. Eng. 


\section{2. 研究の方法}

2002 年 9 月に療養型病床群としては個室コニット化に対応した新 6 病棟（以下：新病棟）を開設した福岡県W町に位置する $A$ 病院を調査 対象とする。入居者・職員・物理的環境亡の関わりについて時系列的 な変化を捉えるために、新病棟開設以前の 3,5 病棟（以下:旧病棟）を 対象に 2002 年 6 月と、新たに開設した新病棟を対象に 2002 年 11 月に 調査を行った。調査は調査者による非参与の行動観察調查と職員への ヒアリング調查を用いている。職員への行動観察調查は朝の $7: 00$ か ら夜の $7: 00$ までの 12 時間、職員 1 人に調査員が 1 人付き、 1 分ごと に職員の滞在場所・行為内容・行為対象者・会話の有無とその内容に ついて調查器具に記録した。高齢者への行動観察調查は朝の $7: 00$ か ら夜の $7: 00$ までの 12 時間、 1 フロアーを調查員 1 人が担当し、 10 分 ごとに高齢者の滞在場所・行為内容・行為対象者・会話の有無とその 内容について調查器具に記録した。定時による1日の観察回数は長期 療養高齢者が73回/人となる。データの取り扱いは高齢者の場合は観 察された回数を「頻度」として取り扱い、それぞれの空間における滞 在数を観察回数で除した值を「滞在割合」として用いている。職員の 場合は調查間隔が1分であるため観察された回数が「時間」となる。ま た、高齢者のプライバシーに配慮し居室内に滞在している際には単に 居室内と記録し居室内での観察調査は行っていない。職員が居室に入 室した場合は調查者は室外に待機し、入室目的がわからない場合は退 室後に入室目的を聞き取る形式にした。

調査当日の職員配置及び長期療養高齢者数を表 1 に、行為分類を表 2に示す。

高齢者一人当たりの職員数は日勤帯で、旧病棟 $3.9: 1$ (看護職員 $11.3: 1$ 、介護職員 $6: 1$ )、新病棟 $3.5: 1$ (看護職員 $7.8: 1$ 、介護職員 6. $5: 1$ ) となっており、若干新病棟の方が手厚い人員配置となってい る。また、新病棟では各フロアーに排泄、入浴介助などの日常業務に は携わらず、レクリエーションの企画準備など業務外の高齢者との

表1.長期療養高粞者数及びスタッフ数

\begin{tabular}{|c|c|c|c|c|c|c|}
\hline & \multicolumn{2}{|c|}{ 3病棟 } & \multicolumn{2}{|c|}{5 病棟 } & \multicolumn{2}{|c|}{ 6病棟 } \\
\hline 長期療莀高 & \multicolumn{2}{|c|}{ 38名 } & \multicolumn{2}{|c|}{ 52名 } & \multicolumn{2}{|c|}{ 39名 } \\
\hline & 看護師 & 介護員 & 看護師 & 介護員 & 看護師 & 介護員 \\
\hline 早出 & 1名 & 1名 & 1名 & 1名 & 0名 & 0名 \\
\hline 常勤 & 1名 & 4名 & 3名 & 6名 & 5名 & 4名(2) \\
\hline 遅出 & 1名 & 2名 & 1名 & 1名 & 0名 & 2名(1) \\
\hline 夜勤 & 1名 & 1名 & 1名 & 2〜3名 & 1名 & 2名 \\
\hline
\end{tabular}
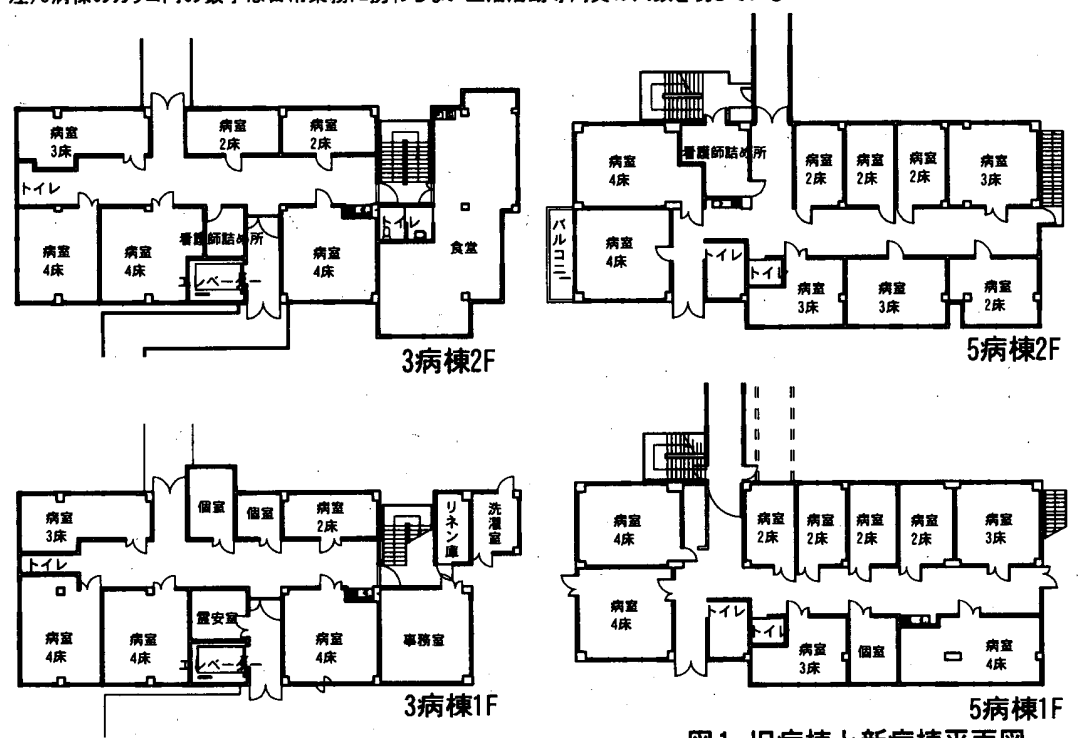

図1. 旧病棟と新病棟平面図
関わりを目的に生活活動専門員 ${ }^{9)}$ を各フロアーに1名配置されている。

行為分類では日本看護協会より看護業務区分 ${ }^{10)}$ が提案されている。 本研究では看護の医療的側面からの評価を意図しておらず、高齢者が生 活を展開していく中で看護・介護職員がどのような関わりを持ちながら 業務を行っているのかということを把握することを意図しているため、 表 2 の行為分類を使用した。

表2. 職員の行為分類

\begin{tabular}{|c|c|c|}
\hline \multicolumn{3}{|c|}{ 医療・リハE゙リ } \\
\hline \multirow{7}{*}{ 介助 } & \multirow{5}{*}{ 身体介助 } & 食事 \\
\hline & & 排泄 \\
\hline & & 入浴 \\
\hline & & 着替え・整容 \\
\hline & & 移動·移乗 \\
\hline & \multirow{2}{*}{ 環境整備 } & 身の回りの世話·環境整備 \\
\hline & & 余层活動 \\
\hline \multirow{3}{*}{\multicolumn{2}{|c|}{ コミュニケーション }} & 日常会話 \\
\hline & & 介助会話 \\
\hline & & 日常会話+介助会話 \\
\hline \multirow{2}{*}{\multicolumn{2}{|c|}{ サポート }} & 役割創出 \\
\hline & & 入居者のメンタルケア \\
\hline \multicolumn{3}{|c|}{ 自己回熳 } \\
\hline \multicolumn{3}{|c|}{ 管理業務 } \\
\hline \multicolumn{3}{|c|}{ 外出 } \\
\hline \multicolumn{3}{|c|}{ その他 } \\
\hline
\end{tabular}

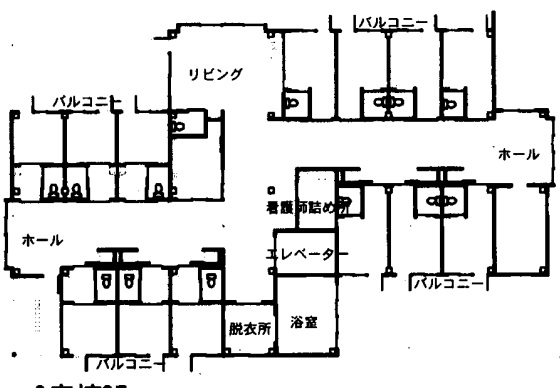

6 病棟 $3 \mathrm{~F}$

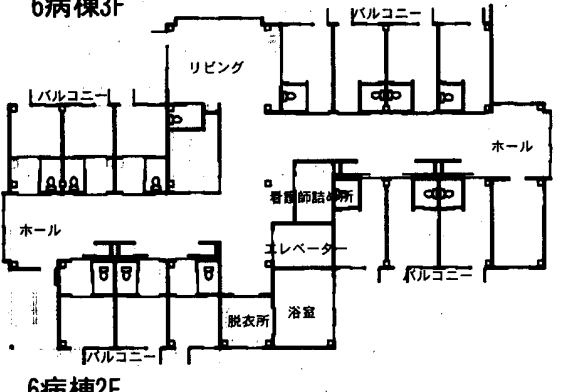
6 病棟2F

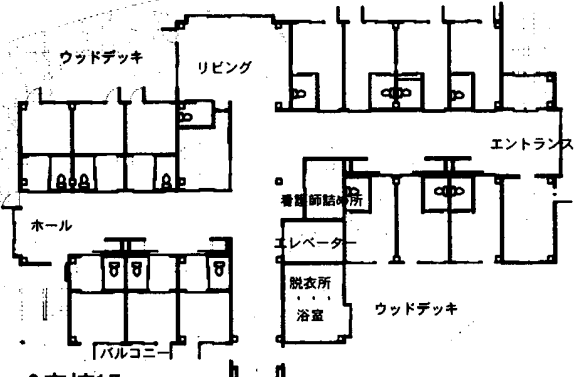
6 病棟 $1 \mathrm{~F}$

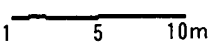




\section{3. 対象施設概要}

調查対象施設の旧病棟と新病棟の平面図を図 1 に示す。 $A$ 病院は平 成 14 年に大規模な改装を行い、全室個室化された新病棟を建設しユ ニットケアの導入を行った全国初の療養型病床群である。また、新病 棟建設により病床数を増やすのではなく、旧病棟を個室化整備のため 改装を行っている。外来患者を診察するI病棟、特殊疾患病棟として 多床室を中心に構成されている2病棟、リハビリ棟などが整備されて おり、今回の新病棟建設、旧病棟改装の結果、新築改装工事以前は 57 室 150 床であったものが 116 室 146 床となっている。

旧病棟と新病棟の空間的な大きな相違点を箅条書きにして挙げると 以下のようになる。

(1)旧病棟では多床室を中心に構成されていた病室が全て個室になっ たこと

(2)個室化された病室に専用のトイレが設けられたこと

(3)旧病棟ではフロアーによってはリビングが設けられていなかった ものが各フロアーにリビングが設けられたこと

(4)旧病棟ではリハビリ棟2階に浴室がありフロアー内に浴室がなっ たのもが各フロアーに浴室が設けられたこと

(5)その他、和室、ホール、バルコニー、ウッドデッキなどの共用空 間が充実したこと

これにあわせて、一括処遇から各フロアーを1 ユニットとしたユ ニットケアを導入した。

\section{4. 調査結果}

\section{1 職員の帯在場所}

図 2 は高歯者の滞在場所を旧病棟と新病棟で比較したものである。 これより高齢者は、旧病棟では居室に日中の8割以上の時間滞在して いたものが、新病棟では居室の割合が4割以下となりリビングが5割を 超える結果となり、居室を中心にした 1 拠点の滞在から居室・リビン グを中心にした2拠点の滞在に変化している。

図 3 は職員の滞在場所を旧病棟と新病棟で看護職員・介護職員と職 業別に比較したものである。高齢者の滞在場所の変化にともない職員 の滞在場所も大幅に変化したことがわかる。職員全体の傾向について 考察すると、旧病棟では職員の滞在場所は高齢者の居室を中心に廊下、 看護師詰め所での滞在が多かったものが、新病棟では居室・廊下に滞 在する割合が大幅に隇少し、リビングでの滞在が5割を超えておりリ ビングを中心に滞在していることがわかる。特養や老健を対象とした 既往の研究では職員の滞在場所と高齢者の滞在場所との関連性が指摘 されている ${ }^{9)}$ が、療養型病床群においても職員と高齢者の滞在場所に は関連性があるといえる。

次に看護・介護と職業別に滞在場所を比較すると、旧病棟では看護 職員と介護職員との間に滞在場所に大きな差異があったものが、新病
棟では滞在場所に大きな差が見られなくなっていることがわかる。旧 病棟では介護職員は居室での滞在が5割を超えており、居室と廊下を 中心に滞在している。居室と廊下での滞在はおよそ8割となり、これ は高齢者の居室滞在の割合とほぼ同じである。一方、看護職員は居室 と看護師詰め所を中心に滞在しており、高齢者の居室の近くに滞在す る割合は5割を切る。旧病棟では介護職員と高齢者の滞在場所には関 連性があるといえるが、看護職員と高齢者の滞在場所での関連性は介 護職員より希薄であったことがわかる。これらの差異の原因は医療に 従事できるかどうかという職能上の問題に最も起因していると考えら れる。新病棟では看護職員と介護職員の滞在場所の格差は解消してい るのであるが、ユニットケアの導入により看護職員もできる限り高鈝

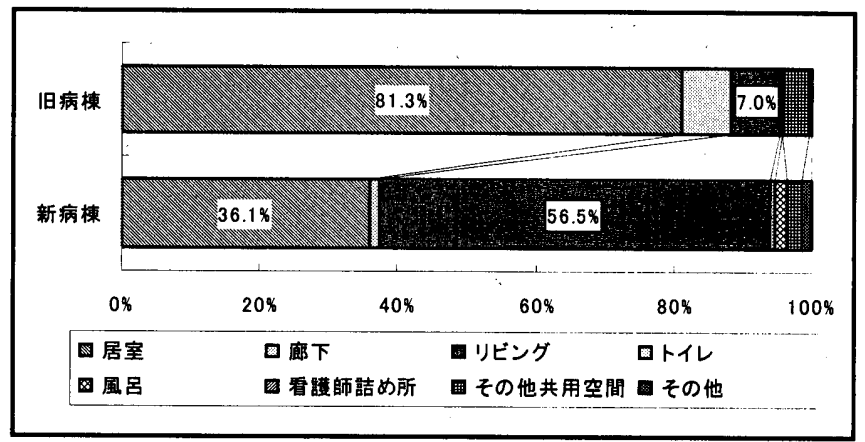

図2 長期療養高齢者の帯在場所の変化

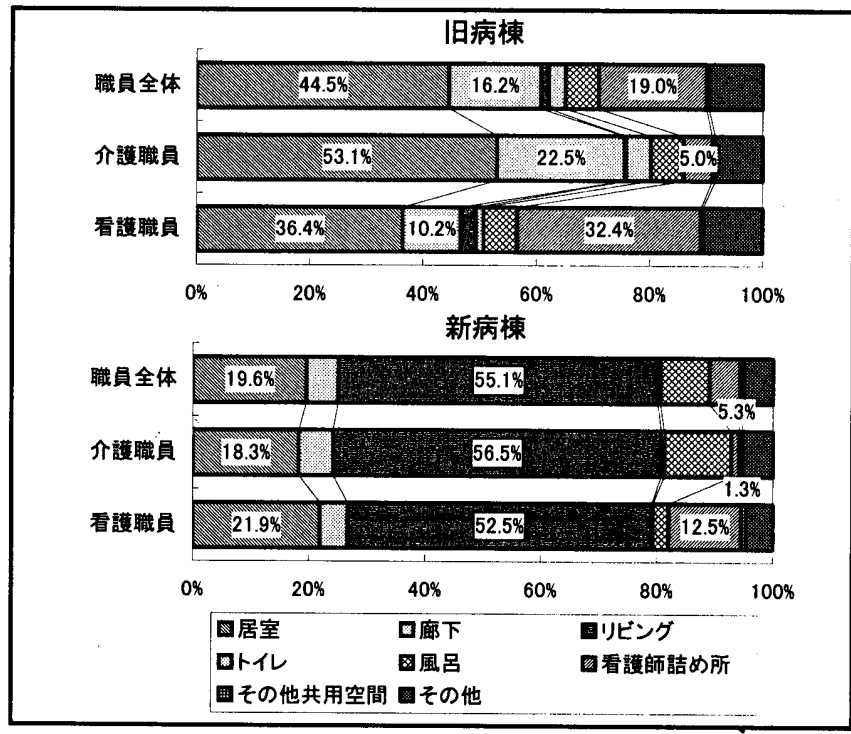

図3 職員の滞在場所の変化

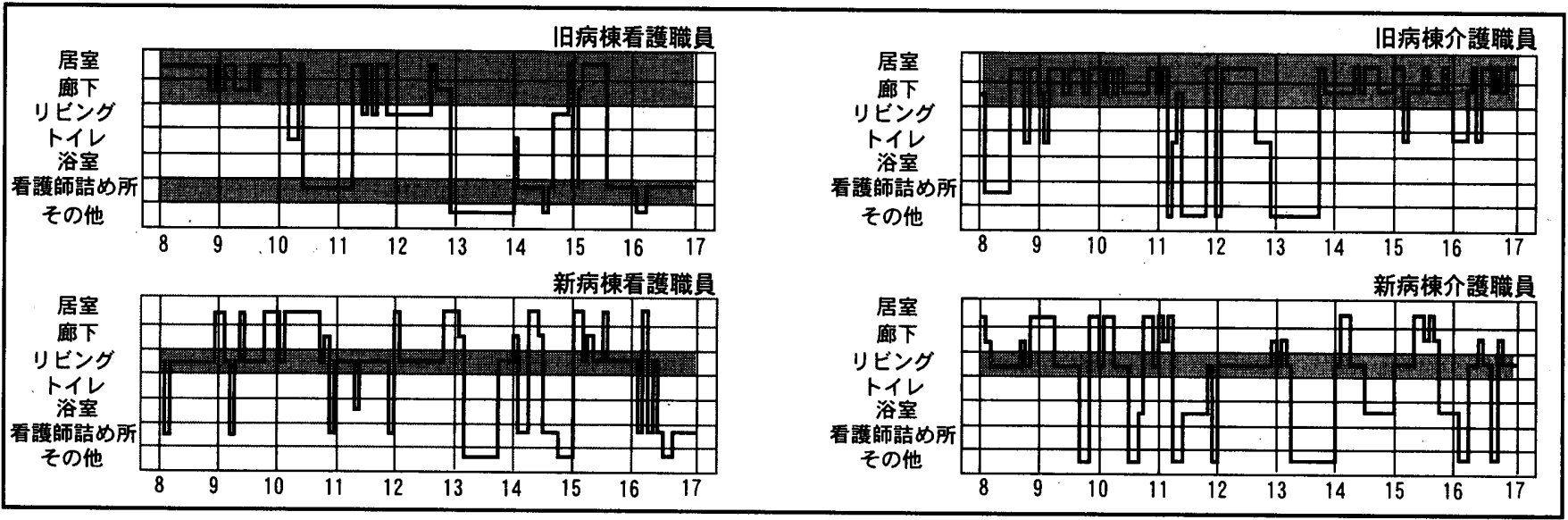

図4 職員別の滞在場所事例 


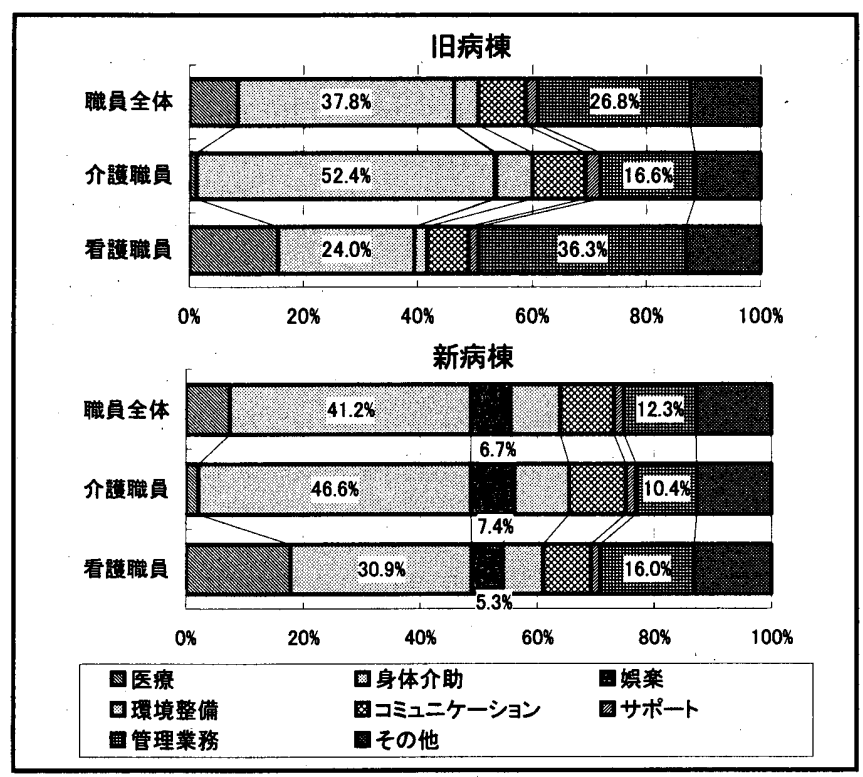

図5 瞕員の行為内容の変化

者と滞在場所を一致させようとする意識の変化が生じたこと、旧病棟 ではリビングなどの共用空間もないフロアーがありスペースさえあれ ば高齢者の側で可能な業務も看護師詰め所を使用せざる得ない状況で あったものが、新病棟ではそれらの空間的問題が解決したことが要因 となっていると考元られる。

図4は看諢職員と介護職員の滞在場所事例を示したものである。旧 病棟では、看護職員の場合は看護師詰め所に滞在する時を除いて、介 護職員の場合は勤務時間帯を通して絶えず高齢者の居室周りに職員が 滞在していたのが、新病楝ではリビングを中心に職員は滞在し必要に 応じて高齢者の居室に滞在していることがわかる。居室が高齢者のプ ライバシーを確保し生活できる場であるならば、職員の居室滞在率が 減少したことは大きな意味があると思われる。

職員の滞在がほとんど見られなかった場についてもふれておくと、 トイレ、その他共用空間があげられる。トイレは全体では $2.9 \%$ から $0.5 \%$ に減少しており、その他共用空間については $0.5 \%$ か $0.6 \%$ と ほとんど変化は見られなかった。トイレについては、旧病棟でも少な かったのであるが居室内に個人用のトイレが完備されているため共用 トイレではなく室内のトイレで排泄が行われているからであると思わ れる。その他共用空間については、旧病棟についてはフロア一内に洗 濯室などの共用空間しかなかったためであるが、新病楝については ホール、和室など共用空間が充実しているもののそこでの滞在はほと んど認められなかった。これは新病棟移行後1ヶ月程度に調查したため 職員間でもこれらの共用空間をどのように利用するか礁認できていな いためであると考えられる。

\section{2 職員の行為内容}

図5は職員の行為内容を旧病棟と新病棟で看護職員・介護職員と職 業別に比較したものである。滞在場所ほど大幅な変化は生じていない が行為内容も変化したことがわかる。職員全体の傾向について述べる 之、管理業務が半減し身体介助、娛楽、環境整備といった行為が增加 したことがわかる。旧病棟でほとんど見られず新病楝で見られるよう になった行為として娛楽行為があげられる。旧病棟では1フロアーに 19〜27 名の高龄者が生活していたものが、新病棟では 1 ユニット 13 名と減少したため空間的な余裕が生まれ、管理業務など業務が効率化 されたため時間的にも余裕が生まれ、リビングなどを利用してプログ ラム的な娛楽行為が可能になったのではないかと思われる。

次に看護・介護と職業別に行為内容を比較すると、旧病棟では看護 職員と介護職員との間に行為内容に大きな差異があったものが、新病 楝ではその差が縮小していることがわかる。旧病棟において看護職員

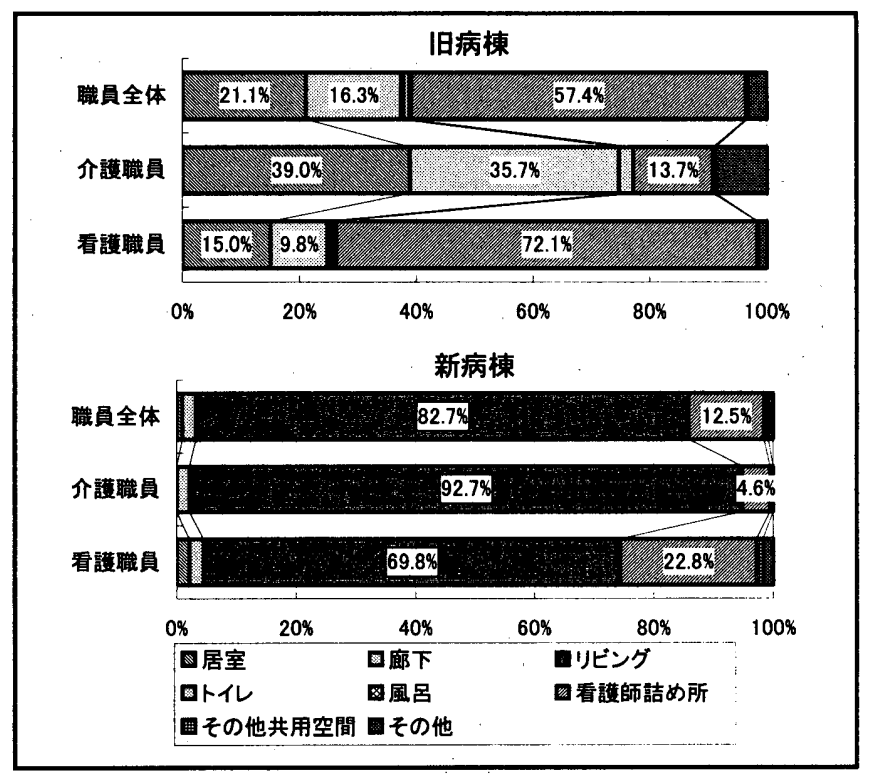

図6 管理業務の行われる場所の变化

の最大の業務は書類作成、物品管理などの管理業務であり、介護職員 は身体介助であった。これは旧病棟において医療に従事できる看護職 員は医療之管理業務、医療に従事できない介護職員は身体介助という 役割分担的な業務の棲み分けがなされていたことがわかる。一方新病 棟では介護職員の身体介助割合が微隇しており、看護職員の身体介助 割合は増加している。また医療と身体介助を合わした時間が高齢者に 直接ヶアを提供する時間であると考えるならば、旧病棟では看護職員 と介護職員との間に大きな差があったものが新病棟ではほぼ同じ割合 を示していることがわかる。職員へのヒアリングによれば、ユニット ケアの導入以後看護職員の意識に今までの役割分担的な棲み分けの業 務ではなく、高齢者の生活を支えるためにユニットがチームとして看 護・介護という立場を超えてお互いに協力すべきであるという変化が 生じている。旧病棟でもこのような意識を持っていたとしても各フロ アーに看護師詰め所がなく、看護職員は自分の担当するフロアーを離 れなければならなかったことを考えると、このような行為内容の変化 に空間が果たしている役割は非常に大きい。調査時に旧病棟と新病棟 に人員配置 (表 2) の差異 (旧病棟 $3.9: 1$ (看護職員 $11.3: 1$ 、介護職 員 $6: 1$ )、新病棟 $3.5: 1$ (看護職員 $7.8: 1$ 、介護職員 $6.5: 1$ )) があ り、空間的要因の他に人員配置の影響もあると考えられる。しかし、管 理業務などは $26.8 \% \rightarrow 12.3 \%$ (看護職員 $36.3 \% \rightarrow 16.0 \%$ 、介護職員 $16.6 \% \rightarrow 10.4 \%)$ と半減しており人員配置の影響より個室ユニット化 の影響の方が強いのではないかと考えられる。

\section{2.1 管理業務が行われる場所}

前項において、職員の行為内容の中で特に管理業務が大幅に減少し、 そこで生まれた時間的余裕が身体介助、娛楽、環境整備といった行為 を增加させていることを示したが、ここでは何故管理業務が効率化さ れたかについて考察してみたい。

図6 は職員が管理業務を行う場所を旧病棟と新病棟で看護職員・介 護職員と職業別に比較したものである。全体の傾向として居室、廊下、 看護師詰め所での管理業務が大幅に減少し、リビングが大幅に増加し たことがわかる。旧病棟では看護師詰め所が6割近い值を示し、居室、 廊下が扰よそ 2 割となっていたものが、新病棟では居室、廊下で管理 業務はほとんど行われなくなり、看護師詰め所も1割強と大幅に減少 し、換わりにリビングが 8 割を超えている。旧病棟においては看護職 員と介護職員の管理業務を行う場所に大きな差異があったが、新病棟 では共にリビングが管理業務を行う中心的な場所になっていることが わかる。旧病棟では看護職員は管理業務のほとんどを看護師詰め所で 行っていたが、介護職員は居室、廊下で管理業務を行っていた。新病 


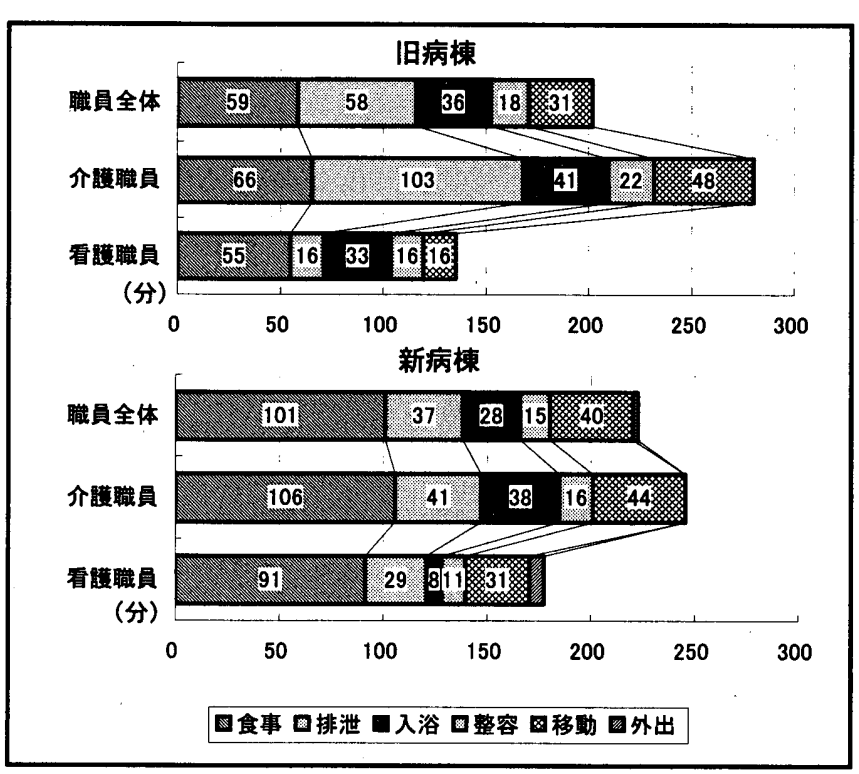

図7 職員 1 人当たりの身体介助内容の変化

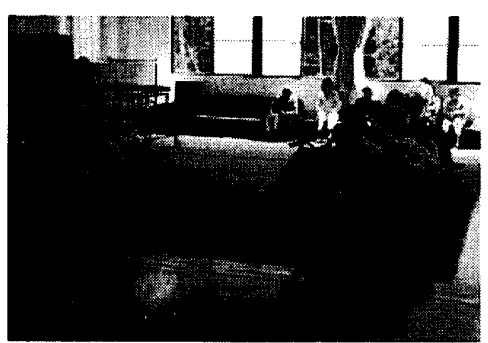

图8 入浴待機中の様子

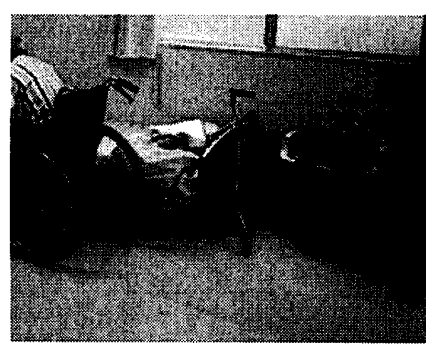

図9居室内のポータブルトイレ
棟ではリビングを利用して看護職員、介護職員が一緒になり管理業務 を行っており、業務の効率化の大きな要因となっていると考えられる。 また、旧病棟では1フロアーに19〜27名の高齢者が生活していたが、 新病棟では1ユニット13名となっており担当する高齢者数が介護単位 の小規模化により減少しているため共有すべき情報量が減少したこと も一因であると推察される。

旧病棟では各フロアーに看護師詰め所が無く、フロアーによっては 担当するフロアーを離れた看護士詰め所で管理業務を行っており、当 然その間は担当する高齢者の状況を確認することができなかった。新 病棟ではリビングを中心に管理業務が行われており高齢者の滞在場所 （図2）考慮すると管理業務中も高齢者の身近に滞在していることを 意味している。管理業務をリビングで行うことは業務の効率化をもた らすだけではなく、職員と高齢者の滞在場所を一致させ業務の間も高 粎者の様子を確認できるようにしているということも空間の変容によ りもたらされた効果である。

\section{2.2 身体介助の時間}

図7は職員 1 人当たりの身体介助時間を旧病棟と新病棟で看護職員・ 介護職員と職業別に比較したものである。旧病棟と新病棟、看護職員 と介護職員とで身体介助時間に大幅に変化が生じたことがわかる。職 員全体の傾向を考察すると、食事介助の時間が40分以上も大幅に増加 し、排泄介助がおよそ 20 分、入浴介助がおよそ 10 分減少したことが わかる。旧病棟では看護職員と介護職員との間に身体介助に携わる時 間に150分近い差があったものが、新病棟ではおよそ60分となってお り差が縮小していることがわかる。旧病棟では、あらかじめ介助する 時間が比較的はっきりしている食事介助や入浴介助では看護・介護と 職能上の違いによる介助時間に差がなく、高歯者の随時性を伴う排泄 介助や移動介助で差が大きいことから、看護職員は医療・管理業務が 中心で、あらかじめ時間が決まっており人手のかかる食事介助と入浴

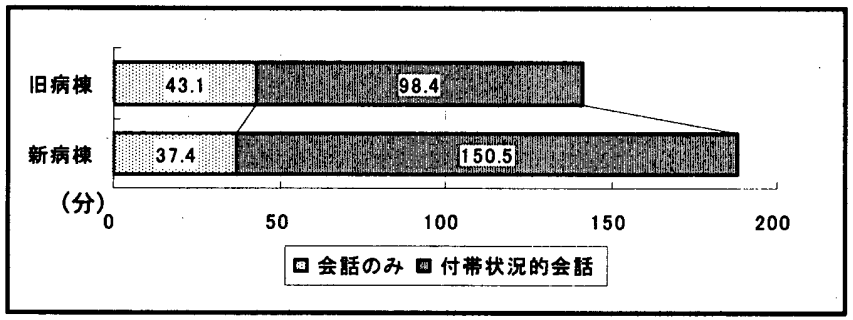

図 10 職員 1 人当たりの会話時間の変化

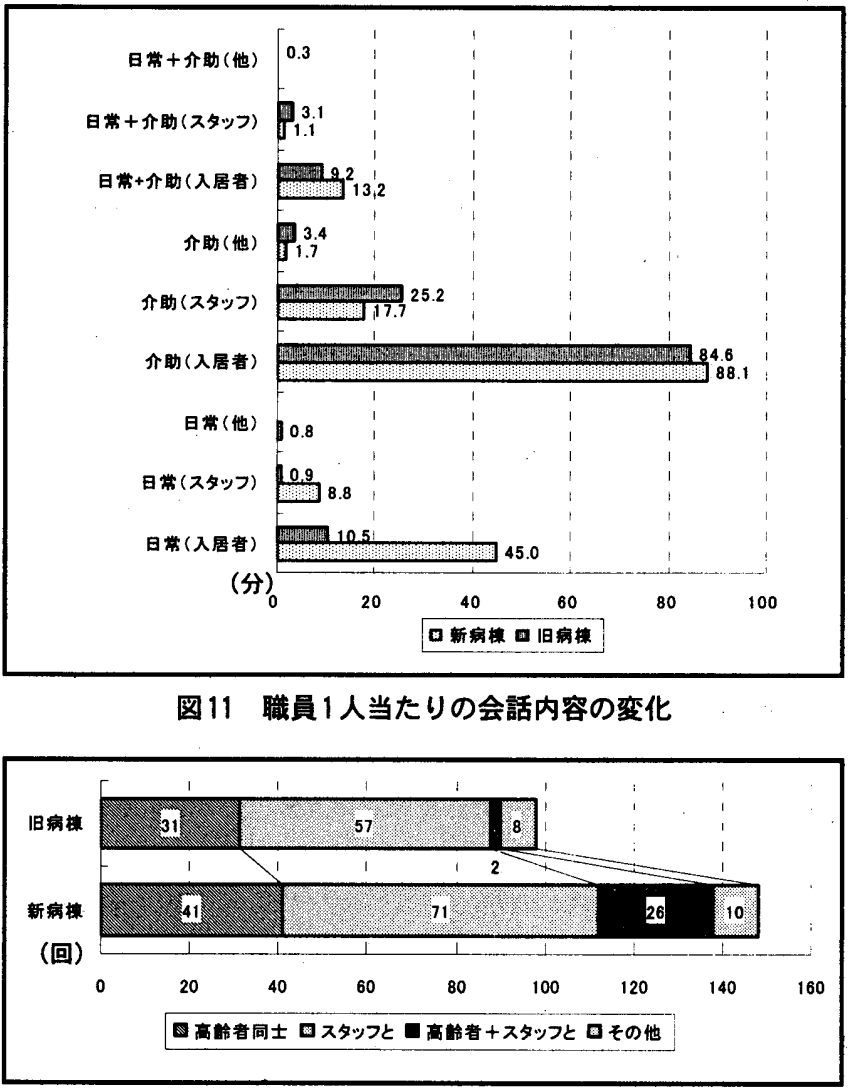

図12 長期療賽高齢者の会話対象者の变化

介助については介護職員を手伝い、排泄介助や移動介助などは介護職 員が基本として行うという、前項でもふれた役割分担的な業務の棲み 分けが行われていた様子がここからもうかがえる。新病棟では看護職 員の身体介助時間は增加し排泄介助なども積極的に行っている様子が わかる。一方、介護職員の身体介助時間は減少しており時間的にも介 助内容的にも役割分担的業務が解消したことがわかる。

個別対応を主とする個室ユニット化は、職員の負担を増やすと思わ れがちであるが、介護行為の中身を見ると、排泄介助と入浴介助の時 間が減少しており職員の負担はむしろ軽減されているといってよい。 入浴介助時間の減少は各ユニットに個浴が設けられたことが大きい。 旧病棟では別棟にある大浴場を利用し、フロア一別に入浴日を決め一 斉の集団入浴を行っていた。フロアー全体の高齢者を浴室に連れて行 き、そのフロアーの職員もほぼ全員入浴介助を行う入浴方式は一見効 率が良さそうに見えるが、待ち時間が長く（図8)、順番待ちの高齢者 へ対応が思いのほかかかる。また大浴槽では自立度の低下している入 居者が姿勢を維持できないため浴槽内にも職員が一定数必要な点など、 実は必ずしも合理的ではなかった。一方、新病棟ではユニットごとに 家庭に近い浴槽を設けた結果、姿勢維持が比較的容易となった。また、 個別的な入浴が、今までの風呂に「入れてもらう」という受動的な感 覚から、風呂に「入る」という積極的な感覚に変化しているというヒ アリング結果が得られている。排泄介助の時間の隇少は、各居室にト イレが完備され分散化されたことが大きい。旧病棟ではトイレの数が 
少なく、主にポータブルトイレを使用していた。ポータブルトイレで の排泄介助はトイレへの誘導 $\rightarrow$ 排泄 $\rightarrow$ トレからの誘導 $\rightarrow$ 污物の処理 という一連の動作を伴うが、トイレが各居室に設けられたことにより 污物の処理がトイレの水を流すだけになった。また、トイレが分散し て配置された結果、高齢者に排泄待ちをさせる必要もなくトイレ誘導 の点においても職員の負担は減少している。このように職員の身体介 助の負担を軽減する上でも空間が果たしている役割は非常に大きい。

\section{3 会話時間とその内容}

図10は職員 1 人当たりの会話時間を旧病棟と新病棟で比較したもの である。会話のみが行われている時間はむしろ若干減少しているが、 食事介助をしながらや管理業務をしながら会話がともなう付帯状況的 会話を加味すると職員の会話時間は50分近く增加していることがわか る。図11は会話内容を日常会話、介助会話、日常会話をともなった介 助会話に分類し対象別に会話内容を示したものである。これより介助 会話では新病棟と旧病棟の間に大きな差は見られないが日常会話で大 きな差が生じていることがわかる。

会話時間、特に日常会話が何故增加したかについて考察を行いたい。 前項でも述べてきたように、新病棟ではリビングを中心にして職員は 滞在している。この結果、職員と高齡者の滞在場所が一致することに より自然発生的に交流が生まれることにより日常会話が増加したので はないだろうか。また、ユニットケアの導入により介護単位が小規模 化されたことにより、職員の中で一人一人の高齢者に積極的に関わっ ていこうとする意識改革が起こっているというヒアリング結果が得ら れており、こういった職員意識の変化というものも日常会話の増加に 非常に大きく関わっていると思われる。

図12は高齢者の会話観察関数を会話対象者別に旧病棟と新病棟で比 較したものである。これより新病棟では全ての対象に対して会話回数

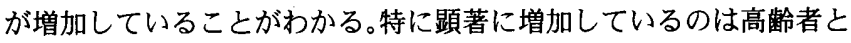
職員を含めた複数人での会話である。職員が高齢者に積極的に話しか け、それが周りの高齢者をも含めた広がりを持うようになったことが ここから読み取れる。また、多床室を中心とした旧病棟より全室個室 の新病棟の方が高齢者同士の会話が増加していることより、職員との 会話が増加しそれが他の高齢者をも含めた広がりを持ち、それが結果 として高齢者同士の交流につながっているのではないだろうか。

\section{5. まとめ}

本研究では療養型病床群として全国で初めて個室ユニット化を行っ たA病院を事例として取り上げ、ユニットケアという介護単位の小規 模化と空間構成の変化が職員にどのような影響を及ぼすのかを詳細に 考察を行った。その内容は以下のようにまとめることができる。

1) 職員の滞在場所が居室、廊下、看護師詰め所を中心としていたも のがリビングを中心に滞在するようになったことを明らかにし、

看護・介護と職能別に高齢者との滞在場所の関連性について考察 を行い、看護職員と介護職員の滞在場所の格差の縮小に空間が果 たす役割の重要性を示唆した。

2)看護職員と介護職員との間に職能上の役割分担が行われていたこ とを滞在場所、行為内容、身体介助内容の比較より明らかにし、そ れがユニットケアの導入による介護単位の小規模化と、それに適 した空間の提供により一括処遇的かつ役割分担的な医療・介護ヶ
アから、医療・介護サービス一体となった個別的ケアへと変化し ていく様子を明らかにした。

3) 空間的問題の解決により業務が効率化することを明らかにし個室 ユニット化が高歯者だけではなく職員にとっても排泄介助や入浴 介助の減少など介護業務の軽滅に有効であることを示した。

4）職員と高齢者の滞在場所の一致、管理業務の効率化、排泄介助や 入浴介助の減少などにより時間的な余裕が生まれ、職員と高齢者 の日常会話が増加したことが明らかになった。職員からの高歯者 への会話が増えたことから、高粉者の会話観察回数も増加し、職 員と高齢者の会話だけでなく、複数の高齢者と職員、高齢者同士 の会話も増加しており、これは以前よりも濃密な人間関係が築か れつつあるものであると考えられる。

本研究では看護職員と介護職員の業務上の差が解消していることに 一定の評価をしている。介護保険 3 施設の中で医療が完備していると いうことが療養型病床群の一つの長所である。高齡者の日常生活の中 に医療サービスと介護サービスを組み込んでいく時に、絶えず高齢者 の生活の身近にいて高齢者と良好な人間関係があるということは大き な意味を持つと考えられる。高齢者との関わりを增やす一つの方法と して介護単位の小規模化をし、その中で今までよりも積極的に介護業 務に携わることは、医療サービスの質の向上にも大きな意味を持つの ではないだろうか。看護職員と介護職員とには医療に従事可能かどう かで職能上の違いは認められるべきであり、介護職員と同量の介護業 務を看護職員に求めるわけではないが、医療と介護という役割分担を 強くするよりは本研究でも述べたように役割分担を縮小することの方 が医療・介護サービスの質の向上につながるのではないかと考えられ る。また、看護職員の介護業務の時間が增えているということは、人 員配置において看護職員を減らし介護職員を増やすという考えもでき る。施設基準や人員配置について様々な視点から議論されるべきでは あるが、そのためにも特養など他の高踚者施設のように研究を蓄積し ていく必要がある。

\section{6. 今後の課題}

本研究では個室ユニット化が職員の行動にどのような影響を与えて いるかを明らかにした。しかし、このような職員の変化と個室化され た空間の変化が高齢者の生活にどのような影響を及ぼしているかにつ いては詳しくふれられてはいない。療養型病床群の特徵として医療が あるが、本研究では提供される医療の実態とそれによる高秢者の生活 への影響につてもふれられてはいない。今後は継続的な調査に基づき 高齢者の生活への影響を明らかにするとともに、旧病棟は改装され個 室化されているか改装事例についても考察を加え、空間的スケールの 違いにより職員と高齢者がどのような影響を受けるのか把握したい。

謝辞

末筆ながら本調查にご協力いただきました病棟職員並びに高齢者の 皆様にお礼を申し上げます。また、生前ご指導いただいた故外山義教 授に、感謝と哀悼の意を表したい。 
【注釈】

1) 平成 12 年 12 月の第 4 次医療法改正により、平成 13 年 2 月以前に「その他の 病床（療養型病床群を含む)」であった病床は、平成 15 年 8 月 31 日までに一般 病床もしくは療養病床のどちらかを選んで届け出ることとされている。2年6ケ 月に及ぶ届け出期間中、療盖型病床群は「経過的旧療養型病床群」という名称で 呼ばれることになる。現在では医療保険に基づく療養病床と介護保険に基づく療 養病床 (介護療盖型医療施設) となる。本研究では調查時期などを考慮し療養型 病床群と表記する。療養病床の施設基淮は療養型病床群の施設基準とほほ同じで あり医療法施行規則において定められていおり、施設基準においては名称変更が 生じただけともいえる。医療保陘適用型と介護保唤適用型との療養病床の施設基 淮の差はなく、人員配置も看護師 $6: 1$ 、介護職員（医療保除適用型の場合は看 護補助者） $6: 1$ と同じである。ただし介護保険適用型の場合は $100: 1$ かつ1人 以上で介護支援専門員を配置する必要があるが、医療保䧍適用型の療養病床の場 合は配置する必要はない (参考文献 1 参照)。また、施設種別の室定員別室数の 個室割合は特盖 $29.3 \%$ 、老健 $27.9 \%$ 、療盖病床等 $18.8 \%$ となっており、今後特 養などが個室化されることを考虑すると差が払大していくことが予想される(参 考文献 2 参照)。

2） 1995 年に特別羔護老人ホームの補助基準が、1人当たり施設面積を $3.3 \mathrm{~m}^{2}$ 引 き上げられ $34.13 \mathrm{~m}$ へ、1人当たり居室面積を $2.4 \mathrm{~m}^{2}$ 引き上げられて $10.45 \mathrm{~m}^{2}$ と なった。特別盖護老人ホームでは 2001 年より全室個室・ユニットケアの新型特 別養護老人ホームの導入を開始した。また老人保健施設でも 2002 年より療養環 境の向上を図る観点から、個室・ユニットケア型施設への改修経費に対する補助 がつく。

3）参考文献 3 参照

4) 参考文献 $4 \sim 6$ 参照

5）参考文献 $7 \sim 11$ 参照

6) 参考文献 12 参照

7) 参考文献 13 参照

8）参考文献 14 参照

9）生活活動専門員は新病棟 1 フロアーに1名ずつ計 3 名配置されている。本文 中にも記述したがレクリエーションの企画準備など業務外の高齢者との関わり を目的に配置されており管理業務や原則として身体介助業務などには携わらな いため本研究では調查対象外とした。

10)看護業務区分は1982年に日本看護協会看護婦職能委員会で看護業務実態調 查を行い、「看護行為分類I」35 項目、「看護行為分類 II」 165 項目に分類し作 成された。時代の変化とともに改訂され、現在は1994年度に再編成されたもの である。医療分野に細部まで分類した看護業務区分の行為分類は看護職員の医 療行為を正確に把握するには有用な行為分類であると思われるが、本研究では 介護職員も同時に行為内容を把挃しなければならないこと、また研究の主眼と して職員が高齢者とどのような関わりを持ちながら業務を行っているのかその 全体像を把握したかったため本文中表 2 の行為分類を使用した (参考文献 15 参 照）

11）参考文献 16 参照
(参考文献)

1) 社団法人日本医療福祉建築協会編集: 医療・高齢者施設の計画法規ハンドブッ ク、中央法規出版、2001

2）日本医師会総合政策研究機構：回復期リ八病棟 / 療㽰病床 / 老健 / 特盖の機 能分担に関する調查研究〜入退院 (所) 分析を中心として〜、日“本医師会総合政 策研究機構、2002

3）外山義他 : ユニットケアのすすめ、筒井書房、2000

4) 石井敏他: 先進事例に見る共用空間の構成と生活の関わり一㾰呆性高齢者の ためのグループホームに関する研究 その1-、日本建築学会計画系論文集 524 、 p109-115、1999. 10

5）厳爽他 : グループホームにおける空間利用の時系列的変化一「なじみ」から みた痴呆性高齢者のケア環境に関する研究 (その1) 一、日本建築学会計画系論 文集 523、p155-161、1999.9

6) 鈴木健二他: 痴呆性高齢者グループホームに拐ける入居者の生活の再編過程 一痴呆性高齢者のケア環境のあり方に関する研究 (1) - 、日本建築学会計画系 論文集 546、p121-126、2001.8

7) 橘弘志他: 特別養護老人ホームの施設空間に展開する生活行動の場一個室型 特別養護老人ホームの空間構成に関する研究 その1-、日本建築学会計画系論 文集 512、p115-122、1998. 10

8) 桶弘志他:特別養護老人ホーム入居者の個人的領域形成と施設空間構成一個室 型特別養護老人ホームの空間構成に関する研究 その2-、日本建築学会計画系 論文集 523、p163-170、1999. 9

9) 橘弘志:特別養護老人ホームのケア環境と入居者の生活展開の比較一個室型特 別養護老人ホームの空間構成に関する研究 その 3 -、日本建築学会計画系論文 集 548、p115-122、2001. 10

10) 㛢弘志: 特別盖護老人ホーム共用空間におけるセミプライベート・セミパフ リック領域の再考一個室型特別養護老人ホームの空間構成に関する研究 その 4 一、日本建築学会計画系論文集 557、p157-164、2002.7

11) 松原茂樹他:入居者に対する介護職員の関わりに関する考察ーユニットケア 型高齢者福祉施設における介護職員のケアのあり方に関する研究一、日本建築学 会計画系論文集 561、p137-144、2002.11

12) 長澤泰他: 病室の最低基淮面積に関する研究報告書 (平成 9 年度課題研究報 告書)、日本医療福祉建築協会、1998

13) 山下哲朗他: 療養型病床群に対応する病棟・病室平面のあり方に関する研究 (平成 6 年度課題研究報告書)、日本医療福祉建筑協会、1995

14) 三浦敏明他: 高齢入院患者の生活展開の類型とその特性に関する考察一療養 環境の変化之高齢入院患者の生活展開に関する研究一、日本建築学会計画系論文 集 523、p139-145、1999. 9

15）日本看護協会看護婦職能委員会 / 編 : 看護婦業務指針、日本看護協会出版 会、 1995

16) 井上由起子他: 高齢者居住施設における個別的介護に関する考察、日本建築 学会計画系論文集 $508 、 p 83-89 、 1998.6$

（2003年 9 月 8 日原稿受理， 2004 年 1 月 20 日採用決定） 